\title{
XIII
}

\section{THE NAME RUSHAN}

By J. F. FleET, I.C.S. (Retd.), Ph.D., C.I.E.

TN a paper at p. 79 above, it is sought to show that the name of the race to which Kanishka and his connections belonged was Kuśa or Kusha; not Kushan or Kushān, as is believed at present. I would invite closer attention to some of the evidence, which hardly seems to bear out such a view: other parts of it are being dealt with by Mr. Allan. ${ }^{1}$

In the accompanying plate, the coins are figured from casts which Mr. Allan has kindly supplied: the Māt inscription is illustrated from an inked squeeze for which I am indebted to Dr. Vogel: the Panjtār inscription is reproduced from General Sir A. Cunningham's original figuring of it: the word Gushana in the Mānikiāla inscription is reproduced from the facsimile given with M. Senart's paper on the record. Mr. Cousens has been so kind as to make the photographs from which the plate has been put together.

\section{The Màt inscription}

As a result of the Kharōshṭhi alphabet not marking long vowels, ${ }^{2}$ and of the Greek alphabet not distinguishing between $a$ and $\bar{a}$, there has been a doubt as to the quantity of the vowel in the second syllable of the name: some writers have used the form Kushān; others of us have preferred Kushan; others have used Kușana, Kushana. The doubt has now been removed, and the Indianized form of the name has been shown, by the inscription, mentioned in footnotes on pp. 80, 87, above,

1 See farther on in this number of the Journal.

2 At any rate, as we have this alphabet in inscriptions and on coins. Downloaded from https://www. cambridge.org/core. INSEAD, on 25 May 2018 at 14:10:41, subject to the Cambridge Core terms of use, available at https://www.cambridge.org/core/terms. 
which was discovered in 1911-12 by Pandit Radha Krishna at Māt near Mathurā. ${ }^{1}$

The inscription consists of four lines, in the Mixed Dialect and Brāhmī characters, on the pedestal of a colossal figure of a Kushān king seated on his throne, and registers the building of a temple with a cloister, a reservoir, and a well. It is not dated; and the king's name is illegible: all that can be said is that it is not a name already known to us, and that the record seems to belong to a period later than the time of Vâsudeva. The king's titles, however, are quite clear ; the words are Mah[ā]rājo, Rājātirājo, D[ē]vaputro, and-

Kushāṇa-putr[o] :

"son or descendant of the Kushānas."

In the form Kushāna thus given, three points for comment present themselves. In the first place, if the name had a long $\bar{u}$ in the first syllable at that time, the writer of this record, using the quite precise Brāhmi alphabet, would have had no difficulty in presenting the name accordingly. But he has given the short $u .^{2}$ And this is borne out by the Greek transliterations, in which we always have $o=u$; not $o u=\bar{u}$. We may take it, then, that the long $\vec{u}$ which we have in the expressions $K \bar{u} \bar{s} \bar{a} n$ ša $h$ and $K \bar{u} \bar{s} \bar{a} n s \bar{s} \bar{a} h \bar{\alpha} n$ ša $h$, traceable elsewhere from about A.D. 300 (see p. 79 above), is a later development.

Secondly; in the second syllable the long $\bar{a}$ attached to the $s h$ is unmistakable.

Thirdly; in respect of the third syllable it may be noted first, as regards something which has been said in note 1 on p. 87 above, that there is distinctly not a subscript $u$ : the plate, indeed, shows below the $n$ some small

1 See the Annual Progress Report of the Superintendent, Hindu and Buddhist Monuments, Northern Circle, for the year ending 31 March, 1912 , p. 2 , para. 5 .

2 The vowel is somewhat blurred, owing to damage to the stone: but it is distinctly recognizable as the short one. 
detached marks which an enthusiast might claim to be remnants of an obliterated $u$; but the back of the squeeze makes it absolutely certain that they are only due to damage to the surface of the stone, and that a subscript $u$ was not contemplated. The vowel, therefore, is $a$. The consonant is distinctly the cerebral $n$. This, in an Indian record, is the natural result of the preceding $s h$, which must turn a dental $n$ into $n$ : it does not bind us to accept the same nasal as belonging to the word in its native form. It is to be added that we cannot find an anusvāra and read $K u s h \bar{a} n a \dot{m}$, and still less $K u s h \bar{a} n \bar{a} \dot{m}:{ }^{1}$ the word is nothing but the base $K u s h \bar{a} n a$, in composition with putro, just like dēva in devvaputro.

This record, therefore, presents the name as $K u s h \bar{a} n a$, in three syllables. The final $a$, however, again, would be a natural Indian feature, for purposes of declension: and the Chinese Kuei-shuang and the Tibetan Gu-zan (see p. 381 below) mark the name as being in its native form dissyllabic, and as ending with a nasal the nature of which is not exactly determinable: and the later form $K \bar{u} \bar{s} \bar{a} n$ is itself in agreement with this. Accordingly, we may take this Indianized Brähmi form as representing an original $K u s h \bar{\alpha} n$, and may now agree to adopt the form Kushān, with the long $\bar{\alpha}$, for all general purposes.

It may be added here that the Kharōshṭi alphabet does not always, if indeed ever, distinguish clearly between the cerebral $n$ and the dental $n$. But the dialect recognized both these nasals. And, in view of the clear spelling Kushäna which we have in this Brăhmi record from Māt, I think we must take it that the Kharōshṭhi presentations of the name, whether in inscriptions or on coins, always intend the cerebral $n$, even if they do not mark it distinctly; just as much as they imply, though they do not show it, the long $\bar{a}$ in the preceding syllable.

1 The marks above the na are only due to damage to the stone; compare similar marks in other places in this record. 


\section{The Panjtār inscription}

This is a Kharōshthin record from the Yūsufzai country, on the banks of the Indus: it seems to have been actually found at a place named Salimpür, near Panjtār; but it has come to be known as the Panjtār inscription. The original stone being now not forthcoming, we are dependent on the two figurings of the record given by Cunningham in JASB, vol. 23 (1854), plate at p. 705, and Reports, vol. 5 (1875), plate 16, No. 4. A reference is made to this record in note 1 on p. 81 above, but in a way which hardly does justice to it; as the result, apparently, of the writer not knowing the earlier figuring of it, reproduced herewith.

The important part of the record is line 1 , which gives the dating : this begins -

Sam 100202 Śravanasa masasa di prathame 1.

Then comes the word maharayasa. This is followed by Gushanasa. And there comes next, at the end of the line, a word of three syllables: here, the first two syllables are unmistakably raja; and the original figuring makes it a moral certainty that the third, which is damaged, was $m i$, giving the quite natural and appropriate word rajami. Accordingly we have-

maharayasa Gushaṇasa rajami.

In the reference to this record, the suggestion is implied that we might perhaps find in Gushanasa an equivalent of the expression $K \bar{u} \bar{s} \bar{a} n$ ša $\bar{h}$, mentioned above (p. 370). To apply the word in that way, however, we must take it as a base in composition with rajami. But the words maharayasa and rajami prevent that. Gushanasa cannot be accepted as anything but the genitive singular of Gushana, in apposition with the genitive singular maharayasa and dependent on the locative rajami. And thus line 1 says :-

"The year 122, the first day, 1, of the month Srävana, in the reign of the great king the Gushana." 


\section{The Māṇikiāla inscription}

This inscription, to which reference has been made in the note on p. 80 above and on p. 84, is another Kharōshthī record, from the Rāwal Piṇ̣̂i District : it has been edited by M. Senart, with a facsimile, in JA, 1896, i, p. 8, and by Professor Liiders in JRAS, 1909, p. 666 .

In the opening passage of this record we have the expression-

\section{Gushana-vaśa-samvardhaka : \\ "an increaser of the Gushāna race." 1}

The first term presents matter for comment. And in the first place I would observe, in passing, that the use of $g$ instead of $k$ in the first syllable seems to connect this record in time with the Paxijtãr inscription, and so to give another reason for looking on it as a somewhat late record : for other remarks on the point of date see JRAS, 1913 , p. 105.

But the syllable in which we are interested here is the third, which both M. Senart and Professor Lüders have read as $n a$, with the dental $n$ and the inherent vowel $a$.

As regards the consonant, I think that, for a reason stated on p. 371 above, we must take it as the cerebral n.

As regards its vowel, the position is as follows. The vertical stem of the $n$ has at the bottom a strong turn to the left. No special value was attached to this feature by M. Senart and Professor Liuders: both of them read the syllable as na. It has, however, now been proposed, on p. 84 above, ${ }^{2}$ to take this detail as meaning the vowel

1 For the general bearing of this expression compare Amgiya-kularadhana, "an increaser of the Amgiya family," in the Nānā Ghāt inscription, ASWI, vol. 5, p. 60, line 3. I am indebted to Dr. Barnett for reminding me of this.

2 The turn to the left is there spoken of as a "hook" : but it does not amount to that, being not in any way curved or bent upwards. The mark which M. Senart (loc. cit., pp. 10-11) dismissed, along with some more or less similar marks attending other letters, as being either a carelessness of the engraver or an accidental mark on the stone, is not this turn to the left, but is the less well defined wedge-shaped mark, Downloaded from https://www.cambridge.org/core. INSEAD, on 25 May 2018 at 14:10:41, subject to the 
$u$, and so to find here the form Gushanu, = Gushānu, and to treat it as the genitive plural of Gusha, =Kusha. But, even apart from the point that the language of the record requires not a genitive but a base in composition with the following term vaśa, an inspection of the $u$ of $g u$, - with which we may compare also the clear and certain $u$ in budhêhi and budhilena farther on in this same record, - will show at once that we have no $u$ in this syllable : to express that, the turn to the left at the bottom of the vertical stem of the letter would have been continued up and back in a loop to the right to meet the vertical again. ${ }^{1}$ We cannot hesitate to agree with M. Senart and Professor Luiders that the vowel of this syllable is $a$; and so we have the name here as Gushana, = Gushāna. The turn to the left at the bottom of the vertical stroke is nothing but a slight exaggeration of the slope to the left with which the Kharōshṭin $n$ often ends, and is quite in agreement with the general sloping character of the writing of this record. It may be noted that the sha also is formed here somewhat exceptionally, in respect of the turn to the left and the bend downwards at the bottom of the vertical stem.

\section{The Shaonano shao coin-legend}

The obverses of the coins of Kanishka, other than those which have a Greek legend in uncial letters, give two legends in cursive Greek letters. One legend,

point downwards, which runs on in continuation of the vertical stem from the point where the turn to the left begins. Professor Lüders, also, attached no value to this mark. It is due, in my opinion, to the surface of the stone splintering and flaking off before the push of the engraving tool. There are marks of the same class, coming down from the line above, over the $s h a$ : and there is something of the same kind on the left of the $u$ of the gu.

1 See also the $u$ of gushanasa in the Panjtär inscription : the earlier figuring, reproduced in the accompanying plate, shows the loop not made completely: the later figuring shows a complete loop, and is perhaps more correct in this detail but either form is admissible. 
apparently found on only the copper coins, is a quite short one :-

\author{
Shao Kanëshki: \\ "King Kanishka."
}

The other legend, apparently confined to the gold coins, is read and understood thus:-

Shaonano shao Kanēshki Koshano:

"King of kings, Kanishka, the Kushān."

This latter legend is also found on the coins of Huvishka and Vāsudēva, both gold and copper, with only the difference in the proper name. As regards the names, it may be noted that in the case of Văsudēva the word is presented sometimes as Bazodēo, quite correctly, and sometimes as Bazoaēo, with the mistake of $a$ for $d$, and sometimes there are other corruptions: in the other cases we have the forms Kanesshki and Kanēshko, and Ooesshki, Ooēshlko, Ooèshke, and Ouoēshki.

The proposal has now been made, on p. 83, to take this legend as beginning (or ending) with the proper name, so as to place Koshano, in either case, before shaonano, and to treat the word, not as a nominative singular in apposition with the proper name, but as a genitive plural dependent on shaonano shao, and thus to find here the equivalent of the expression $K \bar{u} \bar{s}_{\bar{\alpha}} n s_{\bar{\alpha}} \bar{\alpha} \bar{\alpha} n s_{\bar{\alpha}} \bar{\alpha} h$, mentioned above (p. 370). An examination of the coins, however, will soon show that any such alteration of the order of the words of the legend cannot be admitted.

The legend runs round the edge of the coins: and there are two arrangements of it, A and B. In A, which is by far the more common one, the legend begins at the bottom of the coin: in B it begins at the top. ${ }^{1}$ Some clear typical instances are as follows :-

1 This arrangement, B, which seems to have become the prevailing one with the Later Kushāns, is in fact very rare among the earlier coins. There, in addition to B, 1, I find it only on (1) gold coins of Kanishka, in Gardner, plate 26, figs. 16, 17, 18; but the last of these probably Downloaded from https://www.cambridge.org/core. INSEAD, on 25 May 2018 at 14:10:41, subject to the Cambridge Core terms of use, available at https://www.cambridge.org/core/terms. 
A, 1: a gold coin of Kanishka: Gardner, Greek and Scythic Kings of Bactria and India, p. 132, No. 27.1 The word shaonano begins down on the left, beside the king's right foot, below the altar: and Koshano ends on the right, with the final $o$ close to the left foot.

A, 2: a gold coin of Huvishka: Gardner, plate 27, fig. 16. Shaonano begins down below, as in A, 1, on the left of the clouds from which the upper part of the king emerges: and Koshano ends on the right of them.

A, 3: a gold coin of Vāsudēva: Gardner, plate 29, fig. 10. Shaonano begins, again, as in A, 1 and 2, down below, on the left, beside the altar : and Koshano ends on the right, close to the king's left foot.

B, 1: a gold coin of Kanishka: Cunningham, Coins of the Kushāns, plate 17, fig. 12. Shaonano begins up on the right, behind the king's helmet: and Koshano ends up on the left, in front of the helmet.

B, 2: a gold coin bearing the name and legend of Kanishka but not belonging to the original king of this name: Cunningham, plate 17, fig. 8.2 Shaonano begins here, again, up on the right, beside the top of the spear in the king's left hand: and Koshano ends up on the left, over the front of the nimbus.

Thus, the words Koshano and shaonano are regularly separated by substantial parts of the general design of

belongs to the later series : also Cunningham, plate 16, fig. 8 (his fig. $13=$ Gardner, fig. 16) : (2) copper coins of Huvishka, in Gardner, plate 29, figs. 2, 4, and Cunningham, plate 19, figs. E, F : (3) coins bearing the name of Vāsudēva ; gold, in Cunningham, plate 24, figs. C, $\mathrm{D}$, and 12 (legends very corrupt, and probably Later Kushān); copper, ibid., fig. 10 .

${ }^{1}$ 'This has been figured in preference to Gardner's plate 27, fig. 7, because there is a doubt as to the genuineness of the latter coin.

${ }^{2}$ In the right field there is the Brāhmi syllable $p a$; and for this and other reasons the coin is assigned to one of the Later Kushanns, the first successors of the Kanishka-Väsudēva group: see Cunningham in Num. Chron., 3rd series, vol. 13 (1893), pp. 115, 119 ; the coin is figured again there in plate 8, fig. 1. I am indebted to Mr. Allan for drawing my attention to this disposal of the coin. 
the obverse. ${ }^{1}$ And any such separation of the other complete words of the legend is very rare: in fact, the published obverses do not give any instance of separation between the proper name and Koshano, whether by part of the general design or even by a blank space; and only two cases can be cited in which there happens to be a separation between shaonano shao and the proper name. $^{2}$ On the other hand, the proper name of the king is almost always divided, and so is subjected to a treatment which could never be given to the first word of a legend. This happens not to be the case in B, 1, where enough margin was made to carry the legend round unbroken. But in A, 1 Kanesshki is divided by the king's helmet and the top of the spear between $\alpha$ and $n:$ in $\mathrm{A}, 2$ Ooeshli $i$ is divided by the helmet after the first $o$ : in A, 3 Bazoaẽo (for Bazodè) is divided by the diadem and the top of the spear between $\alpha$ and $z$ : and in B, 2 Kaneshki is divided between $\alpha$ and $n$ by the king's feet and the altar.

1 But it is said that every rule has its exceptions: and the remark applies here in a few cases. See, for instance, two gold coins of Vàsudēva: Cunningham, plate 24, figs. A and D. Here we have the usual standing king, with splayed feet and altar. The arrangement of the legend is that of class A above. Shaonano begins down on the left, beside the altar. The $n$ of Koshano stands on the right, beside the king's left foot: but there was no room there for the final $o$; and it was inserted on the left, below the altar, beside the right foot.

See also two other gold coins of the same king: Gardner, plate 29, fig. 9 ; Cunningham, plate 24, fig. 3. The arrangement of the legend is the same. Here, again, the final $o$ is on the left, below the altar, beside the king's right foot. The letters oshan are missing.

See also another gold coin of the same king: Cunningham, plate 24, fig. 4. The arrangement of the legend is again the same. The king's name is presented as Bazoa, with the mistake of $a$ for $d$, and with omission of $\bar{e} o$. The final $o$ of Koshano stands below the space between the king's feet.

Even in these instances, however, it is clear that the legend begins with shaonano shao.

2 One case is the coin of Huvishka figured farther on, C, 2: here, something which projects from the top of the king's head-gear lies between shao and Ooeshko. The other is the coin of Vàsudēva mentioned last in the preceding note: here, again, there is a separation between shao and the proper name, due to the king's diadem. 
In this way, the legend is marked distinctly as beginning always with shaonano. And Koshano stands in such a position that it is difficult to think of any rule for the order of words in a prose sentence according to which it can be a genitive dependent on the term shaonano shao, or even on the proper name.

The evidence, so far, both under this head and in the other lines, is all against the view which is put forward in the paper mentioned above. Now, however, we come to something, overlooked by the writer of the paper, which might certainly be held to bear it out, though not exactly in the form in which it is urged. We find it on two types of Huvishka, which belong to class A above, but add another word at the end of the legend.

c, 1: a gold coin of Huvishka: Gardner, plate 28, fig. 10. Shaonano begins down on the left, beside the clouds on which the king is seated. On the right, Koshano is followed by another shao, which ends on the right of the clouds.

c, 2: a gold coin of Huvishka: Gardner, plate 27, fig. 12. Except for the separation of shaonano shao and Ooeshko by something which projects from the top of the king's head-gear (mentioned in note 2 on p. 377 above), the legend runs all round the coin. Shaonano begins down on the left, behind the elephant's right hind foot. Koshano ends at the bottom, below the animal's right fore foot, and is followed, as on C, 1, by another shao. ${ }^{1}$

Thus, these two coins give the legend in the amplified form :-

\section{Shaonano shao Ooēshko Koshano shao.}

1 This last word was overlooked by Gardner in this case : but Cunningham recognized it; and it is unmistakable. The bottom and part of the body of the $s h$, with part of the $a$, can be seen clearly below the two hind feet of the elephant. The final o perhaps fell outside the coin, along with the top parts of those two letters and of some others on both sides, or perhaps was inserted in miniature close behind the right hind foot. 
Journal Roy. As. Soc. IgI4

The Shaonano shao coin-legend
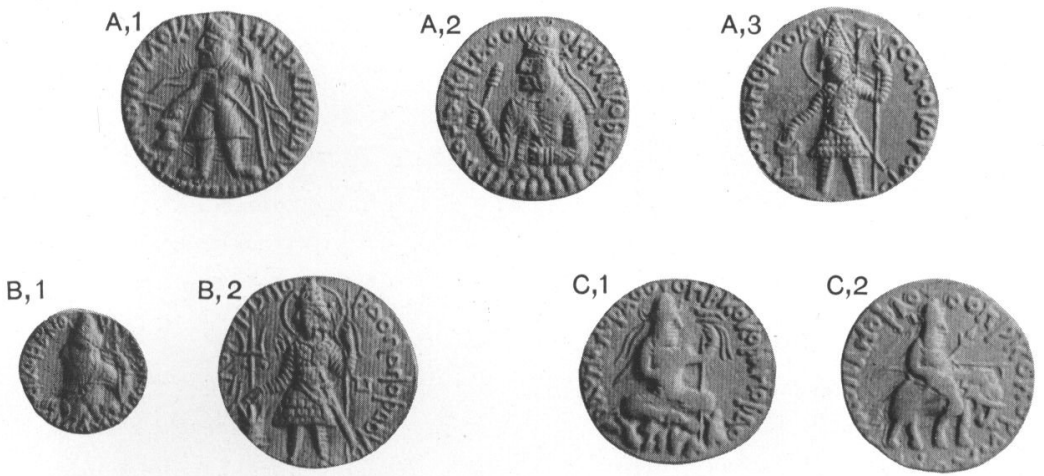

From the Manikiala inscription

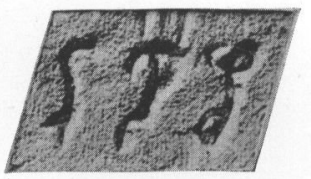

The Panjtar inscription: the year 122

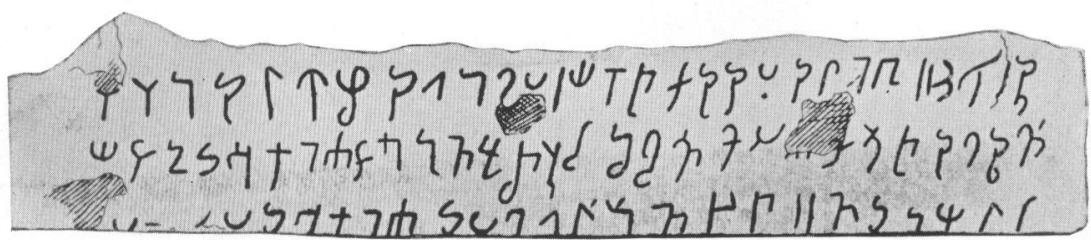

The Mat inscription

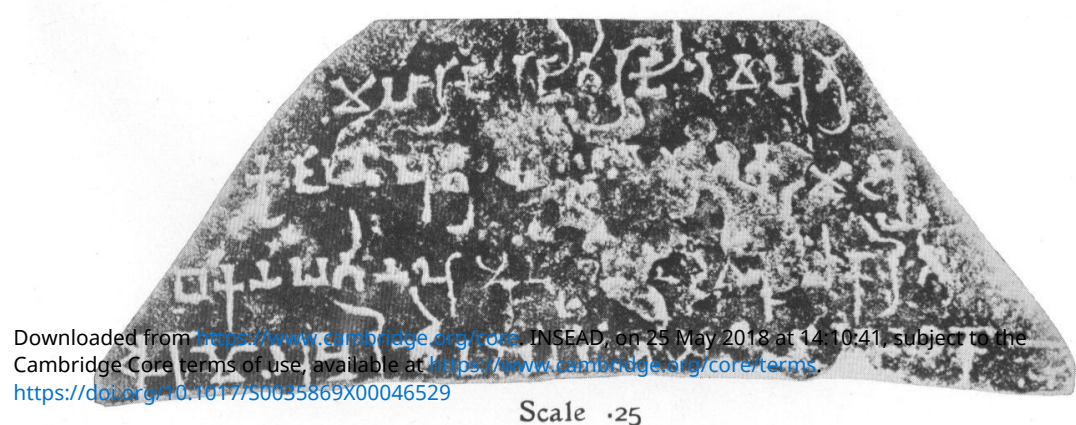


Here, indeed, in Koshano shao we have an exact equivalent of $K \bar{u} s \bar{a} \bar{n} n s \bar{s} h$. But we do not take either Koshano as a genitive plural dependent on shao, or $K \bar{u} s \bar{a} n$ as a similar genitive dependent on $s \bar{a} h$. Though shaonano, = shäunānu, is evidently a genitive plural and the case-ending seems to be $a n o,=\bar{a} n u$, and not nano, = $n \bar{a} n u$, still, even if that word is not a borrowed one but belongs to the same language with Koshano, ${ }^{1}$ it can hardly follow that every word in that language ending in ano, a anu, must be a genitive plural. All the other evidence is in the direction of taking Koshano, $K u s h \bar{a} n u$, as a nominative singular: and there cannot be any difficulty about treating it as such in this case also ; regarding it here, however, as being in apposition with the following word shao, instead of with the proper name. We thus render this legend by:-

"King of kings, Huvishka, the Kushän king."

On the same lines we render the later expressions

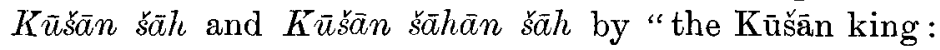
the Kūšãn king of kings."

\section{General remarks}

The ultimate basis of this new proposal about the name of the race is plainly as follows (see p. 86):-

1. The Chinese translation of the Sūträlamkāra of Aśvaghōsha contains a passage which says:--"In the Kusha race there was a king named Kanishka." 2

2. In the Tibetan version of the Mahārājakanikalēkha of Mātrichēta there is an expression by which Kanika (Kanishka) is addressed as " born in the Kuśa race." 3

We are supposed to have thus a name which was written as Kusha or Kuśa, indifferently. It is claimed that we have on the coins, in the Shaonano shao legend,

1 It seems to be admitted that this is a moot-point.

2 JA, 1896, ii, p. 457 : and see Ind. Ant., 1903, p. 385.

3 Ind. Ant., 1903, p. 356, verse 49. 
the genitive plural of that same name in the form Koshano, =Kushānu. And it is proposed to find this genitive plural in at any rate one inscription, where we have been reading, and still can only recognize, the base Gushana, = Gushāna.

But the claim based on the coins falls to the ground at once: it necessitates taking the words of the legend in an order in which they were not intended to be taken. What we really have there is, not $K u s h-\bar{a} n u$ as the genitive plural in $\bar{a} n u$ of a base Kush, Kusha, but $K u \operatorname{sh} \bar{\alpha} n-u$ as the nominative singular in $u$ of a base $K u s h \bar{a} n$ : compare the forms Kanēshlko = Kanēshk-u, and Ooēshko $=(H) u w \bar{e} s h k-u$ (see p. 375 above).

As regards the expression in the Chinese translation of the Sūtra, M. Sylvain Lévi has suggested that it had its origin in the translator having read Kushāañ $\bar{m}$ vamisé, "in the race of the Kushas", by mistake for Kushanavamiśe, " in the Kushana race". ${ }^{1}$. This explanation has been objected to in favour of regarding Kuśa, Kusha, as a shortened form of Kushana. ${ }^{2}$ And another view might be that the word kuśa, already well established in Sanskrit,, would easily recommend itself as a substitute in Sanskrit writings for the foreign name. I venture to think, however, that M. Sylvain Lévi's explanation, which is now supported by the actual occurrence of the name as Kushāṇa in the Măt inscription, is the most likely one for the Sūtra; and that it ultimately accounts equally well for the expression in the Letter.

In any case, the Chinese translation and the Tibetan version seem to furnish poor grounds on which to rely against all the indications which are opposed to the proposition that the name was Kusha or Kuśa. And we

1 JA, 1896, ii, p. 457, note: and see Ind. Ant., 1903, p. 386.

2 Ind. Ant., 1903, p. 348.

${ }^{3}$ In ordinary use, as another term for the sacred darbha-grass; and as a proper name, in the case of a son of Rāma, and in various other instances. 
have from both sources, Chinese and Tibetan, something which is much better than what is deducible from a translation and a version.

From the Chinese we have the transliterated form Kuei-shuang: ${ }^{1}$ and in one of the Tibetan works dealing with Li-yul or Khotan we have the name Gu-zan, which can only be a transliteration of Gushān, Kushān:"The king Kanika and the king of Guzan and king Vijayakirti, lord of Li, and others . . . ." 2

These actual transliterations are much more to the point than translations and adapted versions. They indicate a word of two syllables, ending with a nasal, the nature of which is not exactly determinable. And the same is indicated by the nominative $K u \operatorname{sh} \bar{a} n-u$, which we have in the Shaonano shao coin-legend. From the Mat inscription we have the trisyllabic form Kushāna. This, however, is easily reducible, as stated above, to Kushän; in which shape it matches exactly the Chinese and Tibetan transliterations and the form given by the coins.

In these circumstances it cannot be held that a case has been made out for regarding the name of the race as being anything except Kushän.

1 See the passage quoted on p. 80 above.

2 Ind. Ant., 1903, p. 349. 